\title{
OPTIMAL SHAKEDOWN OF THE THIN-WALL METAL STRUCTURES UNDER STRENGTH AND STIFFNESS CONSTRAINTS
}

\author{
Piotr ALAWDIN ${ }^{1}$, Liudas LIEPA ${ }^{2}$ \\ ${ }^{1}$ University of Zielona Gora, Zielona Góra, Poland \\ ${ }^{2}$ Vilnius Gediminas Technical University, Vilnius, Lithuania
}

\begin{abstract}
Classical optimization problems of metal structures confined mainly with 1st class crosssections. But in practice it is common to use the cross-sections of higher classes. In this paper, a new mathematical model for described shakedown optimization problem for metal structures, which elements are designed from 1st to 4th class cross-sections, under variable quasi-static loads is presented. The features of limited plastic redistribution of forces in the structure with thin-walled elements there are taken into account. Authors assume the elastic-plastic flexural buckling in one plane without lateral torsional buckling behavior of members. Design formulae for Methods 1 and 2 for members are analyzed. Structures stiffness constrains are also incorporated in order to satisfy the limit serviceability state requirements. With the help of mathematical programming theory and extreme principles the structure optimization algorithm is developed and justified with the numerical experiment for the metal plane frames.
\end{abstract}

Keywords: shakedown, optimization, mathematical programming, thin-wall metal structures, strength, stiffness

\footnotetext{
${ }^{1}$ Corresponding author: University of Zielona Gora, Institute of Civil Engineering, Szafrana st 1, 65-516 Zielona Góra, Poland, e-mail: p.aliawdin@ib.uz.zgora.pl, tel.+48683282322

${ }^{2}$ Corresponding author: Vilnius Gediminas Technical University, Department of Structural Mechanics, Sauletekio ave 11, 10223 Vilnius, Lithuania, e-mail: liudas.liepa@vgtu.lt, tel. +37052745216
} 


\section{INTRODUCTION}

The optimization of thin-wall metal (TWM) frames and structures under different load combinations remains important problem today. In reality struc-tures are loaded by the variable repeated quasi-static loads and actions, which are arbitrary varying within known domain. These loads and actions are not pre-scribed by history in time, but only by their given combinations according to Eurocode or any other standard.

Usually these combinations are assumed as independent, what is true only for linear systems. But relatively few papers take into account the mutual in-teraction of load combinations for the nonlinear systems such as real TWM ones. For instance, a thin-wall continuous beam with softening behavior under one-path loading was analyzed by [25] taking into account material non-linearity and local buckling. Sensitivity analysis of the stability problems of thin-walled structures presented in [17]

The right approach is possible either by laborious analyzing of load history in time without any warranty of accounting for the worst histories of independent load cases, or for the entire class of loading as provided in the theory of shakedown analysis (SDA) [1,5,6,8,9,12,14-16,19,20,22,26,27,29-32]. The example of such shakedown approach to the steel frames confined with 1st class cross-sections was published in a paper by Atkočiūnas \& Venskus [10]; a shakedown limit analysis of the reinforced concrete frames has been done by Alawdin \& Bulanov [2]; an updated mathematical model for optimal shakedown analysis of plane reinforced concrete frames according to Eurocodes has been introduced by Alawdin \& Liepa [3].

The design of elastic-plastic metal frames is performed using the Eurocode 3 (EC3) [13] or other standards, but the algorithms for strength and stiffness evaluation of TWM structures elements are not fully described in these standards. The details of analysis and design of such structures have been given in various works [11,28].

In this paper a new mathematical model of SDA and optimization of plane thinwall metal frames, which elements are designed from 1st to 4th class crosssections, is proposed for general nonlinear and simplified linearized case. Structures stiffness constrains are also incorporated in order to satisfy the limit serviceability state requirements. The methodology, algorithms and implementation of metal frames weight optimization is presented and illus-trated by numerical example.

Optimal results obtained, after solving continuous optimization problem, provided the optimal thin-wall metal cross-sectional area and member sizing. That allowed designing cross-sectional area from the manufacturers' catalogue using mixed-integer non-linear programs approach. 


\section{MATHEMATICAL MODELS OF OPTIMIZATION OF THE STRUCTURES}

\section{General mathematical model and assumptions}

Mathematical model in this paper is based on a hypothesis of small displacements; nonlinear or linear mathematical programing theory and finite elements method are used further. The features of limited plastic redistribution of forces in the structure with thin-walled elements there are taken into account [4]. The elasticplastic flexural buckling in one plane without lateral torsional buckling behavior of members is assumed.

The TWM frames structures are loaded by forces $\boldsymbol{F}$ varying in the certain domain $\Omega(\boldsymbol{F})$. A set of the worst load combinations $\boldsymbol{F}_{l}, l \in L$, and corresponded to it a set of the worst inner elastic forces combinations $S_{e j}, j \in J$, may be chosen by procedure suggested by Alawdin [1].

Distribution of frame element parameters (limit inner forces) is optimized here at shakedown under stiffness and nonlinear strength constraints, when load variation, material parameters and lengths $L_{k}$ of all $k$-th elements are known $(k \in K)$.

The general problem of shakedown optimization of TWM frames structures under loads $\boldsymbol{F}$ varying in the certain domain $\Omega(\boldsymbol{F})$ is formulated as follows: find a vector of limit forces $S_{0}=\left(S_{0 k}, k \in K\right)$ of the sections, as well as the vectors of plastic multipliers $\lambda, \lambda_{j}, j \in J$, such, that:

$$
\begin{gathered}
\min f_{0}\left(\boldsymbol{S}_{0}\right), \\
\varphi_{j}\left(\boldsymbol{S}_{e j}+\boldsymbol{G} \boldsymbol{E}_{p} \lambda, \Gamma \boldsymbol{S}_{0}\right) \geq \boldsymbol{0}, \\
\lambda=\sum_{j} \lambda_{j}, \quad j \in J, \\
\lambda_{j}^{T} \boldsymbol{\varphi}_{j}=0, \quad \lambda_{j} \geq 0, \\
\boldsymbol{A} \boldsymbol{G} \boldsymbol{E}_{p} \lambda=\mathbf{0}, \\
\boldsymbol{S}_{0}^{-} \leq \boldsymbol{S}_{0} \leq \boldsymbol{S}_{0}^{+},
\end{gathered}
$$




$$
u_{\text {min }} \leq u_{e, \text { inf }}+u_{r, \text { inf }}, \quad u_{e, s u p}+u_{r, \text { sup }} \leq u_{\max } .
$$

Where $f_{0}\left(\boldsymbol{S}_{0}\right)$ is criterion of optimization; $\boldsymbol{S}_{0}^{-}$and $\boldsymbol{S}_{0}^{+}$are constraints of limit forces $S_{0}$ of the sections; $\Gamma$ is configuration matrix of elements limit forces; $\varphi$ is yield or strength function of the sections; $\boldsymbol{G}$ is a influence matrix of residual forces; $\lambda, \lambda_{j}, j \in J$, are the vectors of plastic multipliers; $\boldsymbol{u}$ is the vector of displacements; indexes $e, r$ mean elastic and residual ones; inf, sup - lower and upper bound of displacement variation accordingly; $\boldsymbol{u}_{\min }, \boldsymbol{u}_{\max }$ - lower and upper constraints of the vectors of displacements.

A diagonal matrix $\boldsymbol{E}_{p}$ assigns a value to the residual internal force in every thinwall element: 1 - if class of element is equal 1 or 2; 0 - if class of element is equal 3 or 4 (i.e. it defines a disposition of the partial plastic redistribution of forces).

A diagonal matrix $\boldsymbol{E}_{p}$,

$$
\boldsymbol{E}_{p}=\operatorname{diag} \boldsymbol{E}_{p k}, \quad k \in K,
$$

assigns a value to the residual internal force in every $k$-th thin-wall element crosssection, $k \in K: 1$ - if class of element is equal 1 or 2; 0 - if class of element is equal 3 or 4 (i.e. it defines a disposition of the partial plastic redistribution of forces); $K$ is a number of element cross-sections.

Dimensionless moment $M$ - curvature $\kappa$ diagram for pure bending of TWM element cross-section is shown in Figure 1.

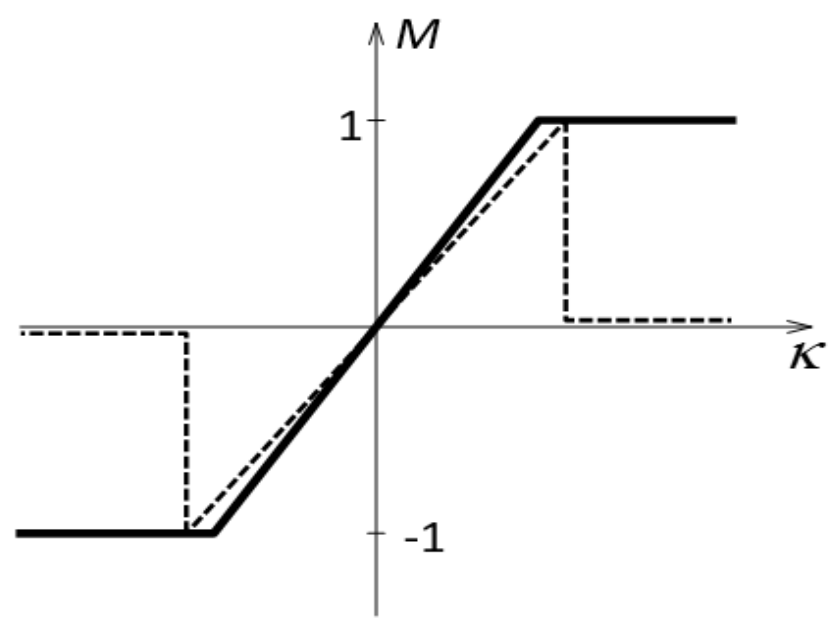

Fig. 1. Moment $M$ - curvature $\kappa$ diagram for pure bending of TWM element crosssection: for Class 1 or 2 ; - - - - for Class 3 or 4 
Namely, if a vector $\boldsymbol{S}$ of structure internal forces consists of the subvectors $S_{k}=\left(M_{k}, N_{k}\right)$ with the bending moment $M_{k}$ and normal force $N_{k}$ in $k$-th element cross-section, submatrix $\boldsymbol{E}_{p k}$ reads as follows:

$$
\boldsymbol{E}_{p k}=\left[\begin{array}{l}
\operatorname{diag}\left[\begin{array}{l}
1 \\
1
\end{array}\right] \text { for Class (1 or 2) } \\
\text { or } \operatorname{diag}\left[\begin{array}{l}
0 \\
0
\end{array}\right] \text { for Class (3 or 4) }
\end{array}\right], \quad k \in K .
$$

If the problem (1)-(8) will have some active inequalities (2) for one and the same element cross-section at proper loads, such regime of plastic yielding will be named sign-changing. In such case we may calculate this element cross-section as elastic.

Inequalities (2) generally depends on the domain $\Omega(\boldsymbol{F})$ of loading [1], checking of this effect may be an actual problem of Code's future variants.

In the formulation of problem (1)-(8) may be included not only the uncertain load, but any other actions, e.g. thermal or kinematic distorsions.

\section{Simplified linearized mathematical model}

For the shakedown problem with stiffness and linearized strength constraints a mathematical model will be as follows:

$$
\begin{gathered}
\min f_{0}\left(\boldsymbol{S}_{0}\right), \\
\boldsymbol{\varphi}_{j}=\boldsymbol{\Gamma} \boldsymbol{S}_{0}-\boldsymbol{\Phi}\left(\boldsymbol{S}_{e j}+\boldsymbol{G} \boldsymbol{E}_{p} \lambda\right) \geq \boldsymbol{0}, \\
\lambda=\sum_{j} \lambda_{j}, \quad j \in J, \\
\lambda_{j}^{T} \boldsymbol{\varphi}_{j}=0, \quad \lambda_{j} \geq 0, \\
\boldsymbol{A} \boldsymbol{G} \boldsymbol{E}_{p} \boldsymbol{\lambda}=\mathbf{0}, \\
\boldsymbol{S}_{0}^{-} \leq \boldsymbol{S}_{0} \leq \boldsymbol{S}_{0}^{+}, \\
u_{\text {min }} \leq u_{e, \text { inf }}+u_{r, \text { inf }}, \quad u_{e, \text { sup }}+u_{r, \text { sup }} \leq u_{\text {max }} .
\end{gathered}
$$

Here $\boldsymbol{\Phi}=\operatorname{diag} \boldsymbol{\Phi}_{i}$ is a quasi-diagonal matrix of the linear yielding conditions (10), $\Phi_{i}$ is the matrix of coefficients of the $i$-th section linear yielding conditions. 
In this case of linear yield conditions (11), the residual displacements $\boldsymbol{u}_{r}=\boldsymbol{H} \boldsymbol{\lambda}$ and residual internal forces $\boldsymbol{S}_{r}=\boldsymbol{G} \boldsymbol{\lambda}$ can be expressed by influence matrices of residual displacements (17) and forces (18):

$$
\begin{gathered}
\boldsymbol{H}=\left(\left(\boldsymbol{A} \boldsymbol{D}^{-1} \boldsymbol{A}^{T}\right)^{-1} \boldsymbol{A} \boldsymbol{D}^{-1}\right) \boldsymbol{\Phi}, \\
\boldsymbol{G}=\boldsymbol{D}^{-1} \boldsymbol{A}^{T} \boldsymbol{H}-\boldsymbol{D}^{-1} \boldsymbol{\Phi} .
\end{gathered}
$$

\section{MEMBER STABILITY CHECK}

\subsection{Design formulae for Methods 1 and 2 for members with class 1,2 and 3,4 cross-sections}

Two different formats of the interaction formulae are provided in EC3, called Method 1 and Method 2. The main difference between them is the kind of presentation of the different structural effects, either by specific coefficients in Method 1 or by one compact interaction facto in Method 2. This makes Method 1 more adaptable to identifying and accounting for the structural effects, while Method 2 is mainly focused on the direct design of standard cases [11].

Both methods deal with the most complex behavior of a single span member subjected to combined bending and axial compression, including all possible interactions and non-linear effects. In Method 1 all the influences of material and geometrical nonlinearities and of interactions between loading components are reflected by separate factors. In contrast, Method 2 uses a reduced number of such factors as a result of globalization of several effects and calibration of the latter on the basis of extensive numerical simulations [11].

\subsection{Elastic-plastic flexural buckling without lateral torsional buckling}

It is known, that steel members show linear behavior in the elastic range and nonlinear behavior in the plastic range $[11,13]$.

The higher the slenderness, the lower the capacity and the less pronounced is the plastic behavior. This ideal material behavior is significantly affected by the presence of residual stresses in rolled and welded sections, which results in nonlinearities even at low load-levels. In this respect a large range of members behave inelastically in principle [11].

EC3 classifies sections to Class 1 and 2, which are defined as capable of developing a full plastic capacity, and sections of Class 3 and 4, which are defined 
as elastic. Such classification is often confusing, especially if these definitions are applied to element behavior.

Recent numerical simulations show that Class 3 sections also develop plastic capacity, so that element-behavior presumably is not or is only partially dependent on the class-definition.

For the Class 3 and 4 sections, plastic capacity is not, or is only partly considered. That is why EC3 differentiates between the interaction formulae for "elasticplastic" Class 1 and 2 sections and "elastic" Class 3 and 4 sections. Because of that, interaction formulae for the Class 3 and 4 section follow the analytically derived equations for flexural buckling.

Members not susceptible to torsional deformation fail in flexural buckling, by inplane or special deflection. These are closed sections or open sections appropriately restrained against torsional deformations, as frequently fount in building structures [11].

\subsection{Axial compression and strong axis bending $\left(N+M_{y}\right)$}

\subsubsection{Members with Class 1 and 2 cross-sections}

Design formulae for the in-plane buckling mode $(y-y)$ for members with Class 1 and 2 cross-sections is as follows:

$$
\frac{N_{E d}}{\chi_{y} N_{p l, R d}}+k_{y} \frac{C_{m y} M_{y, E d}}{M_{p l, y, R d}} \leq 1,0
$$

where

$$
k_{y}=1+\left(\bar{\lambda}_{y}-0,2\right) n_{y} \leq 1+0,8 n_{y}
$$

is an interaction factor (Eurocode 3), determined on basis of geometrically and materially non-linear imperfect analyses (GMNIA) results provided by Ofner [28]:

$$
n_{y}=\frac{N}{\chi_{y} N_{p l}}
$$

is an axial compression parameter;

$$
C_{m y}=0,6+0,4 \psi \geq 0,4
$$

is an uniform moment factor [11], which may differ according to the form of element's moments distribution diagram. 


\subsubsection{Members with Class 3 and 4 cross-sections}

Design formulae for the in-plane buckling mode $(y-y)$ for members with Class 3 cross-sections is as follows:

$$
\frac{N_{E d}}{\chi_{y} N_{p l, R d}}+k_{y} \frac{C_{m y} M_{y, E d}}{M_{e l, y, R d}} \leq 1,0
$$

where

$$
\begin{gathered}
k_{y}=1+0,6 \overline{\lambda_{y}} n_{y} \leq 1+0,6 n_{y} \\
M_{e l, y, R d}=W_{y} f_{y} / \gamma_{M 1}
\end{gathered}
$$

For Class 4 cross-sections the section properties $N_{p l, R d}$ and $M_{e l, y, R d}$, need to be replaced by the resistances calculated from the properties of the effective section area of cross-section $A_{\text {eff }}$ and $W_{\text {eff }}$, as follows:

$$
\begin{gathered}
N_{e f f, R d}=A_{e f f} f_{y} / \gamma_{M 1} \\
M_{e l, y, R d}=W_{y, e f f} f_{y} / \gamma_{M 1}
\end{gathered}
$$

\section{EXAMPLE OF SHAKEDOWN ANALYSIS}

\subsection{Discretization of the structure}

A considered three-storey TWM plane frame (Fig. 2a) is subjected to two independent loads: vertical live load $F_{1}$ (varying $0 \mathrm{kN} \leq F_{1} \leq 80,0 \mathrm{kN}$ ) and horizontal wind load $F_{2}$ (varying $-30,0 k N \leq F_{2} \leq 50,0 k N$ ), see Figure 2b.

Members of the frame structure are designed from standard rolled IPE or HE cross-sections. It is assumed, that members are restrained to prevent both lateral and lateral torsional displacements.

It is being assumed, that structure is designed from members of cross-sectional Classes 1, 2, 3 and 4. For the sake of ease, each frame member has a prescribed Class (Fig. 2a), which remains constant during optimization-design procedure.

Frame members are discretized as beam-column elements subjected to strong axis bending and axial force. Detailed discretization procedure is described in work of Liepa \& Karkauskas [23].

The task is to find an optimal solution of the problem (9)-(16) for determining optimal distribution of limit moments of frame at shakedown. 
Lower bound of limit internal force $\boldsymbol{S}_{0}^{-}$is considered as element's limit critical bending moment $M_{0, c r}^{\min }$, [18]:

$$
M_{0, c r}^{\min }=f_{y} a_{3}\left(\frac{L_{c r}^{2}}{a_{1} \lambda_{l i m}^{2}}\right)^{\frac{b_{3}}{b_{1}-1}},
$$

here $f_{y}$ is characteristic yield strength of steel; $L_{c r}$ is the buckling length of the compression member and it is determined according to the algorithm described in work of Liepa [21]; $\lambda_{\text {lim }}$ is limit slenderness of the member, in this paper for all members of the frame it is considered constant $\lambda \leq \lambda_{\text {lim }}=120$ [24]; $a_{1}, a_{3}, b_{1}, b_{3}$ are relation coefficients of cross-section geometrical characteristics [7].

a)

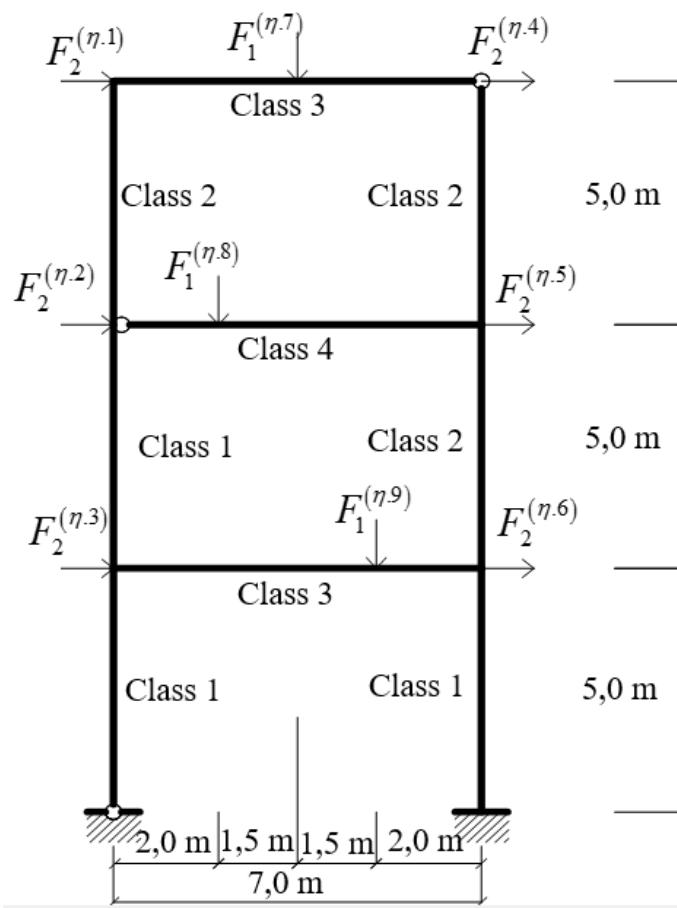

b)

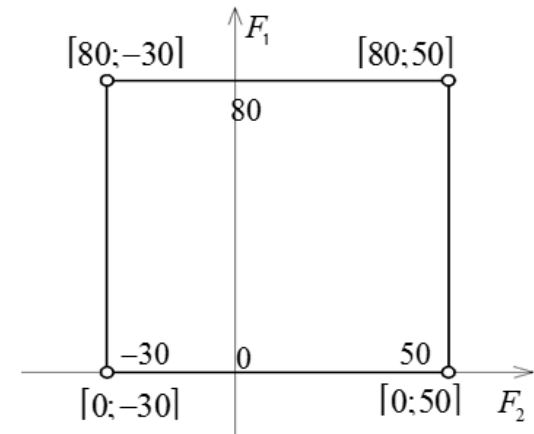

$F_{1, s u p}=80 ; F_{1, \text { bqf }}=0$;

$F_{2, s u p}=50 ; F_{2, \text { ing }}=-30$;

$\boldsymbol{F}=\left[\begin{array}{ll}F_{1} & F_{2}\end{array}\right]^{T} ;$

$\boldsymbol{F}_{\text {sup }}=\left[\begin{array}{ll}80 & 50\end{array}\right]^{T}$;

$\boldsymbol{F}_{\text {inf }}=\left[\begin{array}{ll}0 & -30\end{array}\right]^{T}$.

Fig. 2. Loading scheme (a), load variation locus (b). 
Here $\eta$ a number of load combination (Fig. 2). There are four loading combinations in total, therefore $\eta=1,2,3,4$. Then the generic loading vector has the following form:

$$
\boldsymbol{F}^{(\eta)}=\left[F^{(\eta .1)} F^{(\eta .2)} F^{(\eta .3)} F^{(\eta .4)} F^{(\eta .5)} F^{(\eta .6)} F^{(\eta .7)} F^{(\eta .8)} F^{(\eta .9)}\right]^{T}
$$

And for each combination one can form the following vectors:

Then the wind load (horizontal) is from the left hand side, and combination 1 is formed $\left(F_{1, \text { sup }}+F_{2, \text { sup }}\right)$ :

$$
\boldsymbol{F}^{(1)}=\left[1.1 F^{(1.1)} 1 F^{(1.2)} 0.8 F^{(1.3)} 0.55 F^{(1.4)} 0.5 F^{(1.5)} 0.4 F^{(1.6)} 0.6 F^{(1.7)} 1 F^{(1.8)} 1 F^{(1.9)}\right]^{T} .
$$

And combination $2\left(F_{1, \text { inf }}+F_{2, \text { sup }}\right)$ :

$$
\boldsymbol{F}^{(2)}=\left[1.1 F^{(2.1)} 1 F^{(2.2)} 0.8 F^{(2.3)} 0.55 F^{(2.4)} 0.5 F^{(2.5)} 0.4 F^{(2.6)} 0 F^{(2.7)} 0 F^{(2.8)} 0 F^{(2.9)}\right]^{T} .
$$

Then the wind load (horizontal) is from the right hand side, and combination 3 is formed $\left(F_{1, \text { sup }}+F_{2, \text { inf }}\right)$ :

$$
\begin{aligned}
\boldsymbol{F}^{(3)}=\left[-0.55 F^{(3.1)}-0.5 F^{(3.2)} 0.4 F^{(3.3)}-1.2 F^{(3.4)}-1 F^{(3.5)}-0.9 F^{(3.6)}\right. \\
\left.0.6 F^{(3.7)} 1 F^{(3.8)} 1 F^{(3.9)}\right]^{T} .
\end{aligned}
$$

And combination 4 is formed $\left(F_{1, \text { inf }}+F_{2, \text { inf }}\right)$ :

$$
\begin{aligned}
\boldsymbol{F}^{(4)}=\left[-0.55 F^{(4.1)}-0.5 F^{(4.2)} 0.4 F^{(4.3)}-1.2 F^{(4.4)}-1 F^{(4.5)}-0.9 F^{(4.6)}\right. \\
\left.0 F^{(4.7)} 0 F^{(4.8)} 0 F^{(4.9)}\right]^{T} .
\end{aligned}
$$

Material properties of steel are described in Table 1.

Table 1. Material properties

\begin{tabular}{|c|c|}
\hline Elastic modulus & $E=210 \mathrm{GPa}$ \\
\hline Characteristic yield strength & $f_{y}=235 \mathrm{MPa}$ \\
\hline Partial safety factors & $\gamma_{M 0}=1,0$ \\
& $\gamma_{M 1}=1,0$ \\
\hline
\end{tabular}

Detailed design procedure is shown in a Figure 3. 

STRENGTH AND STIFFNESS CONSTRAINTS

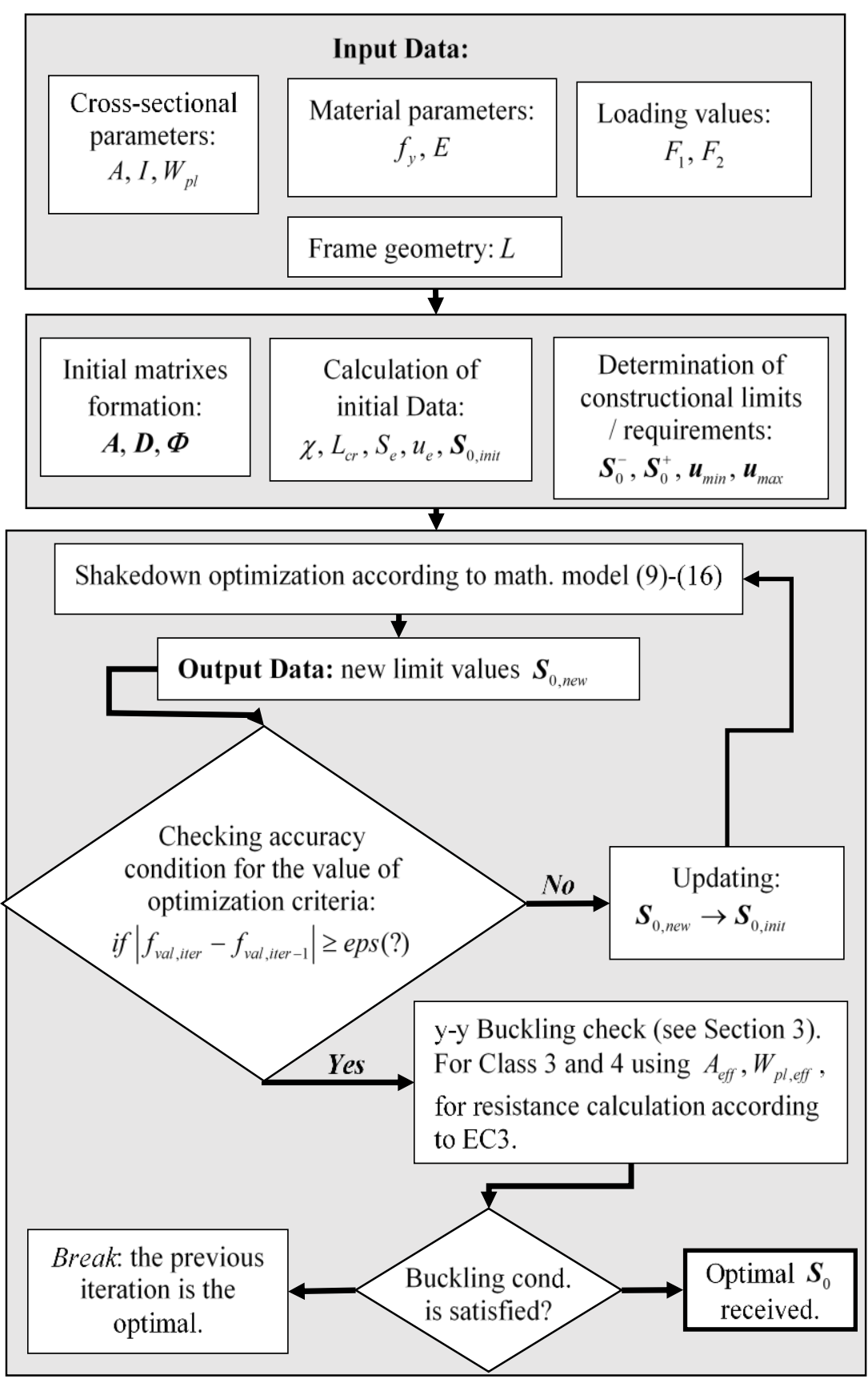

Fig. 3. Shakedown optimization principal scheme 


\subsection{Numerical results}

Optimal solution received after seven iterations (Fig. 4 and Table 2). Optimal limit internal forces distribution obtained when criteria of optimization reached value $f_{\text {val }}^{*}=2,8936 e^{4}$.

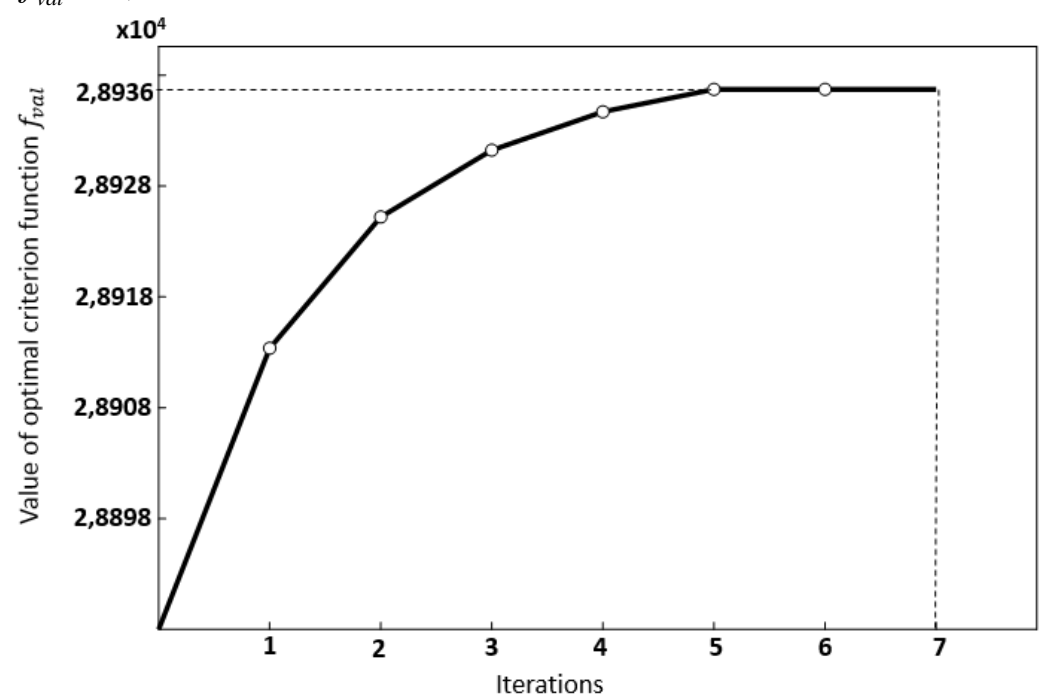

Fig. 4. Optimal solution convergence during iterations

Initial and optimal cross-sectional values of each class are provided in Table 2.

Table 2. Initial and optimal cross-sectional values

\begin{tabular}{|c|c|c|c|c|}
\hline \multirow{6}{*}{ 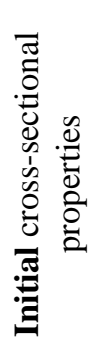 } & Class 1 & Class 2 & Class 3 TWM & Class 4 TWM \\
\hline & HE 300 B & IPE O 400 & IPE 400 & IPE A 360 \\
\hline & $A_{1}^{0}=149,1 \mathrm{~cm}^{2}$ & $A_{2}^{0}=96,4 \mathrm{~cm}^{2}$ & $A_{3}^{0}=84,5 \mathrm{~cm}^{2}$ & $A_{4}^{0}=54,0 \mathrm{~cm}^{2}$ \\
\hline & $I_{1}^{0}=25170,0 \mathrm{~cm}^{4}$ & $I_{2}^{0}=26750,0 \mathrm{~cm}^{4}$ & $I_{3}^{0}=23130,0 \mathrm{~cm}^{4}$ & $I_{4}^{0}=14520,0 \mathrm{~cm}^{4}$ \\
\hline & $W_{p l, 1}^{0}=1869,0 \mathrm{~cm}^{3}$ & $W_{p l, 2}^{0}=1502,0 \mathrm{~cm}^{3}$ & $W_{p l, 3}^{0}=1307,0 \mathrm{~cm}^{3}$ & $W_{p l, 4}^{0}=907,0 \mathrm{~cm}^{3}$ \\
\hline & $M_{01}^{0}=261,9 \mathrm{kNm}$ & $M_{02}^{0}=260,9 \mathrm{kNm}$ & $M_{03}^{0}=521,4 \mathrm{kNm}$ & $M_{04}^{0}=221,2 \mathrm{kNm}$ \\
\hline \multirow{6}{*}{ 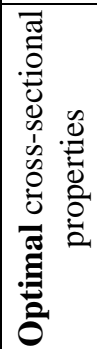 } & & & & \\
\hline & HE 500 B & IPE O 450 & IPE 500 & IPE A 550 \\
\hline & $A_{1}^{*}=238,6 \mathrm{~cm}^{2}$ & $A_{2}^{*}=118,0 \mathrm{~cm}^{2}$ & $A_{3}^{*}=116,0 \mathrm{~cm}^{2}$ & $A_{4}^{*}=117,0 \mathrm{~cm}^{2}$ \\
\hline & $I_{1}^{*}=107200,0 \mathrm{~cm}^{4}$ & $I_{2}^{*}=40920,0 \mathrm{~cm}^{4}$ & $I_{3}^{*}=48200,0 \mathrm{~cm}^{4}$ & $I_{4}^{*}=59980,0 \mathrm{~cm}^{4}$ \\
\hline & $W_{p l, 1}^{*}=4815,0 \mathrm{~cm}^{3}$ & $W_{p l, 2}^{*}=2046,0 \mathrm{~cm}^{3}$ & $W_{p l, 3}^{*}=2194,0 \mathrm{~cm}^{3}$ & $W_{p l, 4}^{*}=2475,0 \mathrm{~cm}^{3}$ \\
\hline & $M_{01}^{*}=807,2 \mathrm{kNm}$ & $M_{02}^{*}=283,4 \mathrm{kNm}$ & $M_{03}^{*}=615,5 \mathrm{kNm}$ & $M_{04}^{*}=565,7 \mathrm{kNm}$ \\
\hline
\end{tabular}


Optimal residual internal forces $\boldsymbol{S}_{r}=\left[M_{r} N_{r}\right]^{T}$ distribution is shown in a Figure 5.

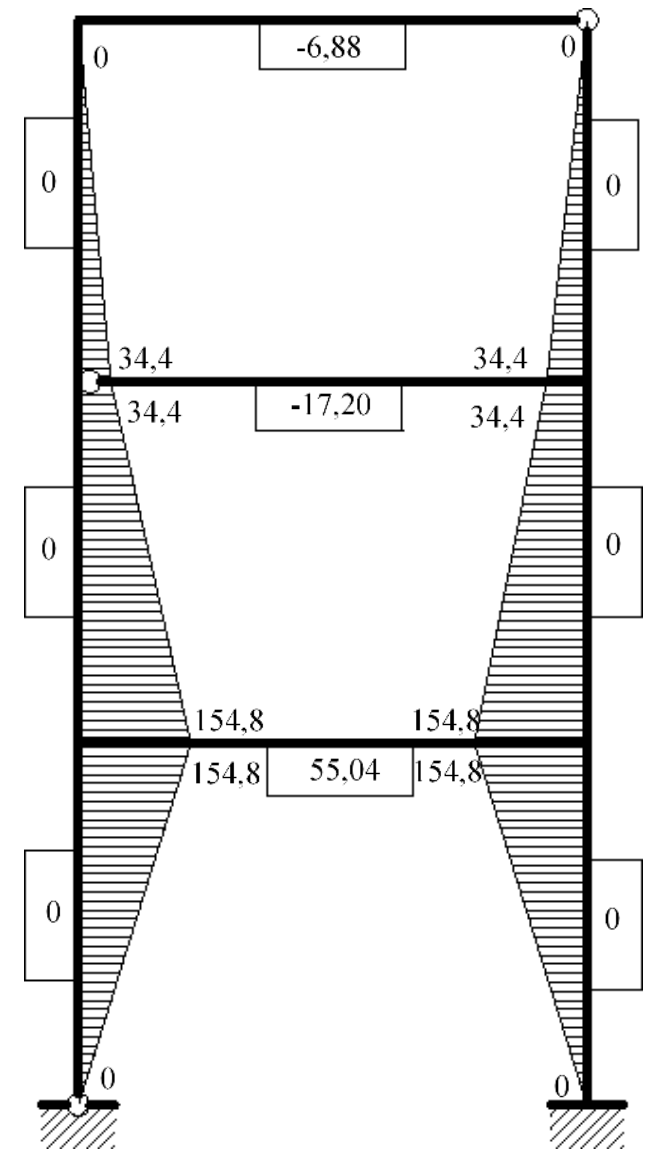

Fig. 5. Residual internal forces $\boldsymbol{S}_{r}$ distribution: moments $k N m$, and axial forces (in squares) $k N$

\section{CONCLUSIONS}

In this paper a new mathematical model of shakedown and optimization of thinwalled metal plane frames, which elements are from 1st to 4th class crosssections, under variable repeated uncertain loads, is proposed for general nonlinear and simplified linearized case. Any possible mechanisms of system 
collapse at shakedown such as plastic yielding and sign-changing ones are analyzed, the partial plastic redistribution of forces in such structures are found. The conditions of elements strength are derived according to the Eurocode 3 . The methodology, algorithms and implementation of TWM frames weight optimization is presented and illustrated by numerical example. Results showed, that updated strength conditions could be used in an optimization mathematical model of frames.

Overall structure experienced shakedown, although Class 3 and 4 elements where designed according to thin-wall metal cross-sections design requirements by EC3, preventing any residual actions occurrences by updated mathematical model condition (13).

The optimal solution for the plane frame under variable repeated loading was obtained by solving mixed-integer optimization problem, which requires a choosing of cross-sections from manufacturers' catalogue.

Further investigation needs to be carried out taking into account the effect of shear forces in the frame elements, torsion and bidirectional bending moments for the three dimensional frames at shakedown conditions.

A dependence of elements strength conditions on the domain of loading may be an actual problem for Code's future variants.

In the formulation of problem proposed here might be naturally included not only uncertain loads, but any other actions and environmental influences, material properties and geometrical data.

\section{REFERENCES}

1. Alawdin P. Limit Analysis of Structures under Variable Loads. Minsk: Tekhnoprint; 2005. http://isbnplus.org/9789854647272.

2. Alawdin P, Bulanov G. Shakedown of Composite Frames Taking into Account Plastic and Brittle Fracture of Elements. Civ Environ Eng Reports. 2015;15(4). doi:10.1515/ceer-2014-0031.

3. Alawdin P, Liepa L. Optimal shakedown analysis of plane reinforced concrete frames according to Eurocodes. Int J Mech Mater Des. December 2015. doi:10.1007/s10999-015-9331-0.

4. Alawdin P, Muzychkin Y. Limit analysis of structures with destructible elements under impact loadings. Eng Trans. 2011;59(3):139-159.

5. Atkočiūnas J. Mathematical models of optimization problems at shakedown. Mech Res Commun. 1999;26(3):319-326. doi:10.1016/S00936413(99)00030-0.

6. Atkočiūnas J. Optimal Shakedown Design of Elastic-Plastic Structures. Vilnius, Lithuania: Vilnius Gediminas Technical University; 2012. doi:10.3846/1240-S. 
7. Atkočiūnas J, Karkauskas R. Optmization of Elastic Plastic Beam Structures. Vilnius, Lithuania: Vilnius Gediminas Technical University; 2010. doi:10.3846/1137-S.

8. Atkočiūnas J, Merkevičiūtè D, Venskus A. Optimal shakedown design of bar systems: Strength, stiffness and stability constraints. Comput Struct. 2008;86(17-18):1757-1768. doi:10.1016/j.compstruc.2008.01.008.

9. Atkočiūnas J, Norkus A. Method of fictitious system for evaluation of frame shakedown displacements. Comput Struct. 1994;50(4):563-567. doi:10.1016/0045-7949(94)90027-2.

10. Atkočiūnas J, Venskus A. Optimal shakedown design of frames under stability conditions according to standards. Comput Struct. 2011;89(3-4):435443. doi:10.1016/j.compstruc.2010.11.014.

11. Boissonnade N, Greiner R, Jaspart JP, Linder J. Rules for Member Stability in EN 1993-1-1: Background Documentation and Design Guidelines. European Convention for Constructional Steelwork; 2006. http://www.steelconstruct.com/site/index.php?module=store \&target=public Store\&id=19.

12. Borino G. Shakedown Under Thermomechanical Loads. In: Hetnarski RB, ed. Encyclopedia of Thermal Stresses. Dordrecht: Springer Netherlands; 2014. doi:10.1007/978-94-007-2739-7.

13. BS EN 1993-1-1. Eurocode 3: Design of steel structures. Part 1-1: General rules and rules for buildings. 2005.

14. Čyras A. Mathematical Models for the Analysis and Optimization of Elastoplastic Structures. Chichester, UK: Ellis Horwood Limited; 1983.

15. Čyras A, Atkočiūnas J. Mathematical model for the analysis of elastic-plastic structures under repeated-variable loading. Mech Res Commun. 1984;11(5):353-360. doi:10.1016/0093-6413(84)90082-X.

16. Kala Z. Global sensitivity analysis in stability problems of steel frame structures. $J \quad$ Civ Eng Manag. 2016;22(3):417-424. doi:10.3846/13923730.2015.1073618.

17. Kala Z. Sensitivity analysis of the stability problems of thin-walled structures. J Constr Steel Res. 2005;61(3):415-422. doi:10.1016/j.jcsr.2004.08.005.

18. Karkauskas R. Optimisation of geometrically non-linear elastic-plastic structures in the state prior to plastic collapse. J Civ Eng Manag. 2007;13(3):37-41. doi:10.1080/13923730.2007.9636436.

19. König JA. Shakedown of Elastic-Plastic Structures. Vol 7. Amsterdam: Elsevier; 1987. doi:10.1016/B978-0-444-98979-6.50018-9.

20. Leonetti L, Casciaro R, Garcea G. Effective treatment of complex statical and dynamical load combinations within shakedown analysis of 3D frames. Comput Struct. 2015;158:124-139. doi:10.1016/j.compstruc.2015.06.002. 
21. Liepa L. Geometrically Nonlinear Analysis of Elastic-Plastic Frame. 2012. http://vddb.laba.lt/obj/LT-eLABa-0001:E.02 2012 D_20120723_ 105737-68422.

22. Liepa L, Blaževičius G, Merkevičiūtė D, Atkočiūnas J. Structural shakedown: a new methodology for estimating the residual displacements. J Civ Eng Manag. 2016;22(8):1055-1065. doi:10.3846/13923730.2016.1217924.

23. Liepa L, Karkauskas R. Calculation of elastic-plastic geometrically nonlinear frames. Sci - Futur Lith. 2012;4(4):326-334. doi:10.3846/mla.2012.51.

24. LST STR 2.05.08:2005. Plieninių konstrukcijų projektavimas. Pagrindinès nuostatos.

25. Mistakidis ES, Stavroulakis GE. Nonconvex Optimization in Mechanics. Vol 21. Boston, MA: Springer US; 1998. doi:10.1007/978-1-4615-5829-3.

26. Narayanan R, Roberts TM. Structures Subjected to Repeated Loading: Stability and Strength. London and New York: Elsevier; 1991.

27. Nguyen Q-S. Min-Max Duality and Shakedown Theorems in Plasticity. In: Nonsmooth Mechanics and Analysis. Boston: Kluwer Academic Publishers; :81-92. doi:10.1007/0-387-29195-4_8.

28. Ofner R. Traglasten Von Staben aus Stahl bei Druck und Biegung. 1997.

29. Venskus A, Kalanta S, Atkočiūnas J, Ulitinas T. Integrated load optimization of elastic-plastic axisymmetric plates at shakedown. J Civ Eng Manag. 2010;16(2):203-208. doi:10.3846/jcem.2010.22.

30. Weichert D, Maier G, eds. Inelastic Behaviour of Structures under Variable Repeated Loads. Vienna: Springer Vienna; 2002. doi:10.1007/978-3-70912558-8.

31. Weichert D, Ponter A, eds. Limit States of Materials and Structures. 1st ed. Springer Netherlands; 2009. doi:10.1007/978-1-4020-9634-1.

32. Zouain N. Shakedown and Safety Assessment. In: Stein E, de Borst R, Hughes TJR, eds. Encyclopedia of Computational Mechanics. Vol 2. Chichester, UK: John Wiley \& Sons, Ltd; 2004:291-334. doi:10.1002/0470091355.ecm031.

\section{OPTYMALIZACJA PRZYSTOSOWANIA CIENKOŚCIENNYCH KONSTRUKCJI METALOWYCH PRZY OGRANICZENIACH ICH NOŚNOŚCI I SZTYWNOŚCI}

Streszczenie

Klasyczne problemy optymalizacji konstrukcji metalowych dotyczą głównie klasy 1 przekrojów. Jednak w rzeczywistych konstrukcjach cienkościennych często stosują się przekroje wyższych klas. W niniejszej pracy zaproponowano nowy model matematyczny dla optymalizacji przystosowania konstrukcji metalowych, w których przekroje 
elementów odnoszą się zarówno do klasy 1 jak i do 4 łącznie, przy obciążeniach zmiennych quasi-statycznych. Uwzględniono możliwości ograniczonej redystrybucji sił resztkowych w konstrukcji z elementów cienkościennych. Autorzy zakładają sprężystoplastyczne wyboczenie na skutek zginania w jednej płaszczyźnie, bez wyboczenia bocznego na skutek skręcania. Wzory obliczeniowe według Metody 1 i 2 dla elementów są analizowane. Ograniczenia sztywności są również zastosowane w celu spełnienia wymogów stanu granicznego użytkowalności. Za pomocą teorii programowania matematycznego i ekstremalnych zasad stworzono algorytm optymalizacji konstrukcji i uzasadniono w eksperymencie numerycznym dla płaskich ram metalowych.

Słowa kluczowe: przystosowanie, optymalizacja, programowanie matematyczne, metalowe konstrukcje cienkościenne, nośność, sztywność

Editor received the manuscript: 06.07.2016 